\title{
分光レーザーの開発と泌尿器科手術への応用 Fundamental and clinical studies of laser dividing system
}

\author{
吉川 哲夫 \\ 日本大学医学部泌尿器科学教室 \\ T173 東京都板橋区大谷口上町 $30-1$
}

Tetsuo YOSHIKAWA

Department of Urology, Nihon University School of Medicine

\begin{abstract}
要 旨
ファイバーカプラー法を応用して1本のファイバーで尊光されたレーザー光を 2 本のファイ バーに分光するレーザー分配装置を開発した。分光されたファイバーを試作したピンセットの両 脚に装着して、Bipolar Laser Forceps（双極レーザーピンセット）として目的部分を把持しな がら2方向よりのNd：YAGレーザー照射を行った。これを用いたレーザー手術の可能性につい て，基礎的実験と臨床応用を行った。

ファイバーカプラー法により 2 本のファイバーに分光することが可能であり，本分光による工 ネルギー損失は少なく $(6.0 \%)$ ，左右の出力差 $(2.0 \%)$ も最小限であった。さらにこの方法は レーザー発振装置を改良する必要はなく既存の発振装置に接続可能である。

基碟実験よしてラット腎血管を用いてその凝固切開能を検討した。平均14.5 Jのエネルギーに て無出血下で片側㹂茎部切断が施行可能であり，しかも組織学的検討より，その熱効果はきわめ て限局していることが確認された。

臨床的に奏際の泌尿器科手術に応用し, その効果を検討した。比較的低出力で目的部分の外科 的処理（凝固，切開など）が容易に効率上く行い得ることが確認された。さらにファイバーを内 視鏡チャンネルに㨉入することにより，内視鏡的使用も可能であることが示唆された。

キーワード：ファイバーカプラー法, 双極レーザーピンセット, Nd：YAGレーザー
\end{abstract}

\section{Abstract}

Bipolar laser forceps (BLF) were developed by the application of fiber coupler method in order to divide one laser beam into two transmissions.

Divided laser fibers were attached to each tip of a pair of forceps; then Nd:YAG lasers were irradiated from different directions through these forceps grasping an object.

After the irradiation activity was confirmed by means of fundamental investigations, BLF were applied to several clinical operations. Bio-physical studies revealed the possibility of laser beam division. The energy loss from division was $6 \%$ and the difference 
in power output between both laser fibers $2 \%$. The conventional laser system was applicable to this method if the fiber coupler was connected to.

As a basic experiment, coagulation and cutting were attempted on the renal vessels of rats. As a result, the vessels were completely transected at an energy output of 14. 5 J. An histological examination revealed a localized thermal damage around the irradiation area.

BLF were then applied to several urological operations for the clinical evaluation. At a low power output, bipolar laser irradiation demonstrated excellent coagulating and cutting effect during the surgical procedure.

According to the present experience, therefore, it was suggested that the use of BLF would be indicated for a greater area including endourology.

Key Words : Fiber Coupler, Bipolar laser Forceps, Nd:YAG Laser

\section{I 緒 言}

今日，臨床領域においてレーザーは先進医療技術とし てその需要をますます拡大している。その需要にこたえ るべく新しい機器および照射法を開発することが必要に なっている。従来, Nd：YAGレーザーは導光ファイ バーの先端を目的組織の近傍に設置し，ファイバーと組 織学接触させずに照射する非接触照射法が行われてきた。 最近ではレーザーの照射効果を増強させるため, ファイ バー先端に接触用プローブを装着し，直接組織に接触し て照射する接触照射法も開発され，様々なレーザー照射 法の改良が試みられてきたり"゙。しかしいずれの場合で も, 一本のファイバーからの照射, すなわち単一ファイ バーが用いられてきた。この単一ファイバーによる照射 においては，まず非接触照射法では，Nd：YAGレー ザ一の笚一方向における深達性によって組織は凝固，蒸 散といった变化を呈していく。このため，深部の熱効果 の判定が困難となり過剩照射が抗こり問題となることが

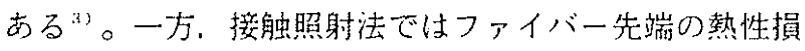
傷などの欠点があるものの，目的組織在王迫した状態で は，より早くかつ低エネルギーで確実に組織の凝固蒸散 といった目的を達成できる。さらに目的組織の損賃を最 小限にして，ある特定の部位に照射するには多方向から の同時照射が理想的である。

そのことから，接触照射の特性を生かし，かつ 2 方向 から目的組織へレーザーを照射する方法が臨床的には最 適と考えた。その達成し得る方法として, Bipolar Laser Forceps（双極レーザーピンセット，以下BLF）を考 案した。以下これを用いたレーザー手術の可能性につい て，基礎的実験と臨床灾用を行ったので報告する。

\section{II 基礎実験}

1. 予備実験

a) ハードウェアー

レーザー発振装置ししてLasersonic 社製Nd：YAG

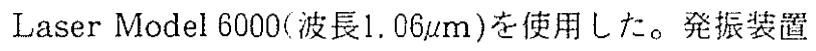
より発生したレーザー光をコア径 $250 \mu \mathrm{m}$ の石英ファイ バーで導光しこれをファイバーカプラー法を応用して作 成したレーザー分配装置(藤倉電線株式会社慗)により同 径 2 本のファイバーに分光した(図１）。この２本のファイ バーでもって2方向よりの1点照射姿試みるため, 試作 したピンセットの両脚にファイバーを装着した（図２）。 その各々のファイバーからの先端出力をパワーメーター で測定した。発生装置で $5 \mathrm{~W}$ 表示の場合 2 本の総合出力

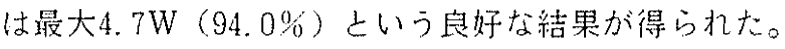
また 2 本間の出力差は0.09W ( 2 本間薄光率差2.0\%) であり，各ファイバーより，平均 $2.25 \mathrm{~W}$ から $2.34 \mathrm{~W}$ の安 定した出力を得ることができた。以上により本システム は実験系に適灾できる等光システムと考えた（表1）。

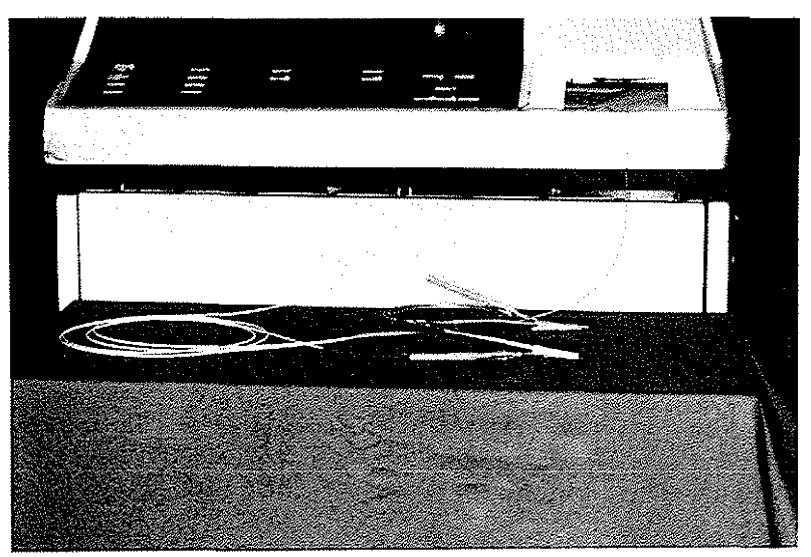

図1分光レーザー装置の概観 


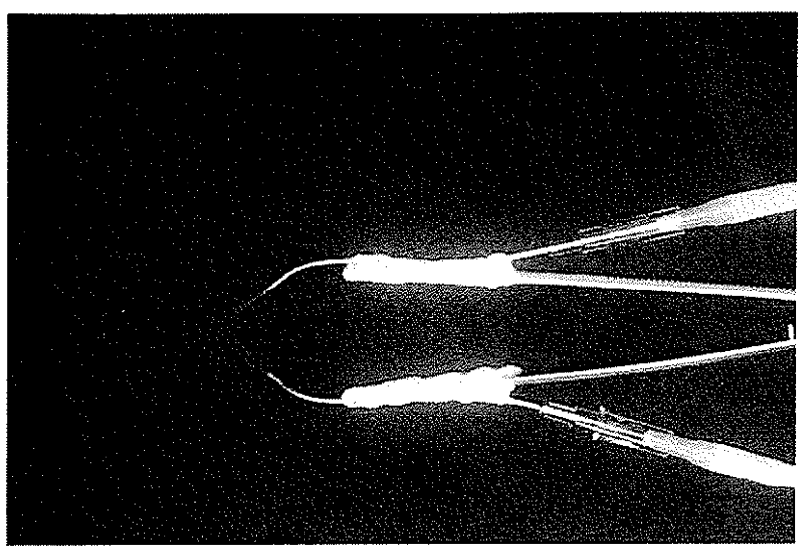

図 2 双極レーザーピンセット

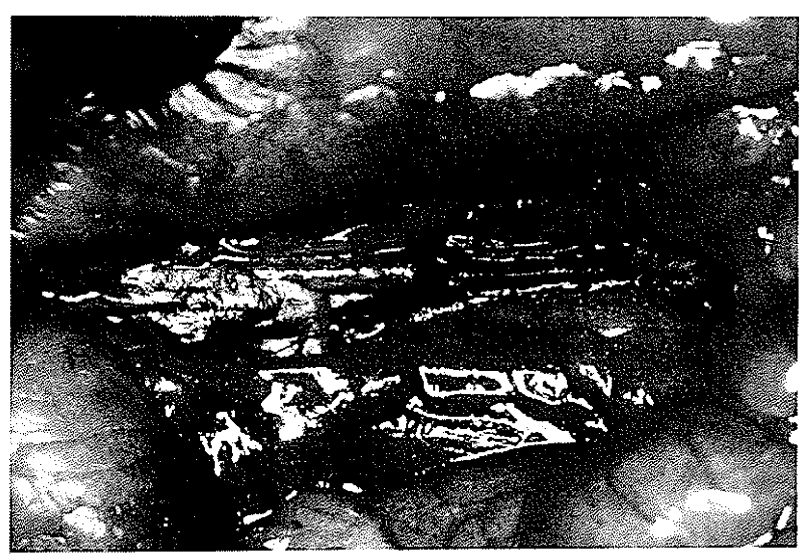

図 3 BLFによるレーザー照射後の血管

\section{b ）レーザー照射条件の設定}

適切な照射条件を設定するため、ラット腸間膜血管(平 均径0.7mm）に対して照射した。目的部分をBLF用ピン セット先端にて把持し，軽く圧力を加えた状態で照射し

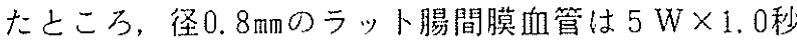
(5.0 J) のエネルギーでもって，BLFピンセットで挟 まれだ組織には幅3. $5 \mathrm{~mm}$ の熱性变化領域を認めた。直径 mm以下の血管在対象にした場合，5.0 J 照射群之5.0 J 以 上の照射群との間で血流遮断効果について娭討したよこ ろ， 2 群間に有意な効果差はなかった。また径 $2.0 \mathrm{~mm}$ 上の血管(ラット大血管) は血流㵂断が可能なものの, 照射法，把持法などに工夫を要することがわかった。よっ て以下BLFによる実験系として照射エネルギー5.0 J以 下に直径2.0 mm以下の血管を対象に本奏験を施行するこ とにした。

\section{2. 目的}

動物実験にてBLFによる組織，特に脈管の凝固切開 能に関する基礎実験を行った。

\section{3. 対象および方法}

対象としてはWistar采雄性ラット（平均体重280g）を 用いた。ネンブタールにより全身麻能を施した後に開腹 し婜門部を露出した。腎動静脈に対して，BLFにより
表 1 分光された左右ファイバーの出力

\begin{tabular}{|c|c|}
\hline 出 力 (W) & $M \pm S D$ \\
\hline 右 & $2.25 \pm 0.07$ \\
\hline 左 & $2.34 \pm 0.06$ \\
\hline 合 & $4.54 \pm 0.17$ \\
\hline
\end{tabular}

表 2 ラット腎血管徍と血流遮断に要し たエネルギーとの関係

\begin{tabular}{|c|c|}
\hline & $\mathrm{M} \pm \mathrm{SD}$ \\
\hline 血 管 径 $(\mathrm{mm})$ & $1.5 \pm 0.1$ \\
\hline エネルギー $(\mathrm{J})$ & $14.9 \pm 1.4$ \\
\hline 先端出力 $3.5 \mathrm{~W}, 0.5$ 秒反射照射 $(\mathrm{n}=10)$
\end{tabular}

Nd：YAGレーザー照射を行って片側腎摘出を施行し， その血流遮断効果を検討した。以上の処置を施したラッ 卜8匹を2 匹ずつ 4 群に分けだ。すなわち第 1 群では処 置を行った直後に, 第 2 群は 2 日後, 第 3 群は 7 日後, 第 4 群は60日後にそれぞれラットを屠殺し，以下に示す ような肉眼的, 組織学的検討をくわえた。

まず第 1 群に対して，照射による脈管の血流遮断効果， 出血の有無, 周囲組織への熱性变化を肉眼的観察の後に 摘出した。ホルマリン固定後H-E標本を作成して組織学 的桱討を行った。光顕的観察では主に照射の局所および 周囲組織の变化に注目して検討した。さらに第 2 群，第 3 群および第 4 群では片側腎摘後に閉腹してそれぞれ 2 日後，7日後および60日後における変化を第 1 群之同様 にして組織学的検討を行った。な打動物実験に際しては 動物愛護の立場を留意して行っだ。

\section{4. 結 果}

第 1 群ラットにおいて，腎血管径と血流遮断に要した エネルギーとの関係を示した（表 2)。雨側先端出力合 計 $3.5 W ， 0.5$ 秒反復照射にて，平均径 $1.5 \mathrm{~mm}$ の腎静脈扩 よび周囲組織が，平均 $14.9 \mathrm{~J}$ のエネルギーにより凝固切 断され，腎摘出を施行し得た。摘出部分の肉眼的所見は 出血，高度の周囲組織の熱性变化老認めず，血管はきん ちゃく状に閉鎖されていた（図 3 )。

ラットのBLF照射後の婜血管の变化に対して経時的 に光顕的検討を加えた結果, 第 1 群では切断部にレー ザーの熱效果による惩血および熱性凝固炭化が認められ たが，第 2 群以下での検討では，血管局所におけるこれ らの熱变化の所見は2 日，7日，60日後之経時的に軽減 していた。一方, 周囲組織の変化について着目すると, 第1群から第 4 群の間に差は認められず，ともに軽微な 変化のみで，レーザーによる熱効果はきわめて限局して 
表 3 BLF照射後のラット腎血管の変化に対する 光顕的検討

\begin{tabular}{|c|c|c|c|c|c|}
\hline & & 第 1 群 & 第 2 群 & 第 3 群 & 第 4 群 \\
\hline \multirow{3}{*}{$\begin{array}{l}\text { 血管局所 } \\
\text { の変化 }\end{array}$} & 熱性凝固 & $(+)$ & $(+)$ & $(+)$ & $(-)$ \\
\hline & 内腔の䈭血 & $(+)$ & $(++)$ & $( \pm)$ & $(-)$ \\
\hline & 化 & $(+)$ & $(t)$ & $(+)$ & $(-)$ \\
\hline \multirow{3}{*}{$\begin{array}{l}\text { 周囲組織 } \\
\text { の変化 }\end{array}$} & 細胞浸潤 & $(-)$ & $(+)$ & $( \pm)$ & $(-)$ \\
\hline & 熱 変 性 & $( \pm)$ & $( \pm)$ & $(-)$ & $(-)$ \\
\hline & 化 & （士） & $( \pm)$ & $( \pm)$ & $(-)$ \\
\hline
\end{tabular}

(H) 高度, $(+)$ 中等度, (

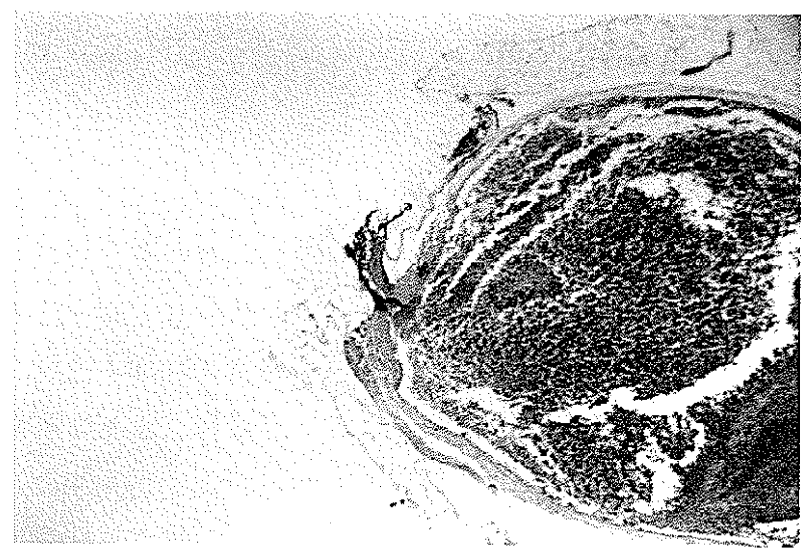

図 4 BLFによるレーザー照射 2 日後の組織像

いた（表 3)。一例として，第 2 群の向管組織像をみる 上，局所所見としての熱性凝固，内腔の娟血，炭化なよ゙ が認めら机るものの，周国組織の变化としては若Fの細 胞浸溜，炭化がみられる程度で，熱変性を思わせる所見 は認めら扎なかった（図 4)。さらに60日後の血管維織 像では、レーザ一照射の影響と考えら机る局所扩上び周 囲組織の变化はまったく認めら机なかった。

なお全例において，実験中の出血死もしくは閉腹後儌 青中の死亡例は経験しなかった。

\section{III 臨床応用}

\section{1 . 目的}

基礎実験の成果をふまえて，BLFの臨床的有用性に 関して検討した。

\section{2. 対象および方法}

我々の施設における泌尿器科手街の中で，䧔监内，陰 茎, 腸管, 外尿道口小腫湯の切除および内視鏡下手術に 扮ける小血管の処理なよ゙を主たる目的として，BLFを 試みた。基礎実験と同様にピンセット操作に準じて目的 部分を把持し局所の血流を遮断した状態で，先端出力 3 $\mathrm{W}$ (双極合同)，0.2秒反復照射穻行っだ。患者，術者， 助手をはじめ在室者はレーザー防御用の眼鏡を着用する

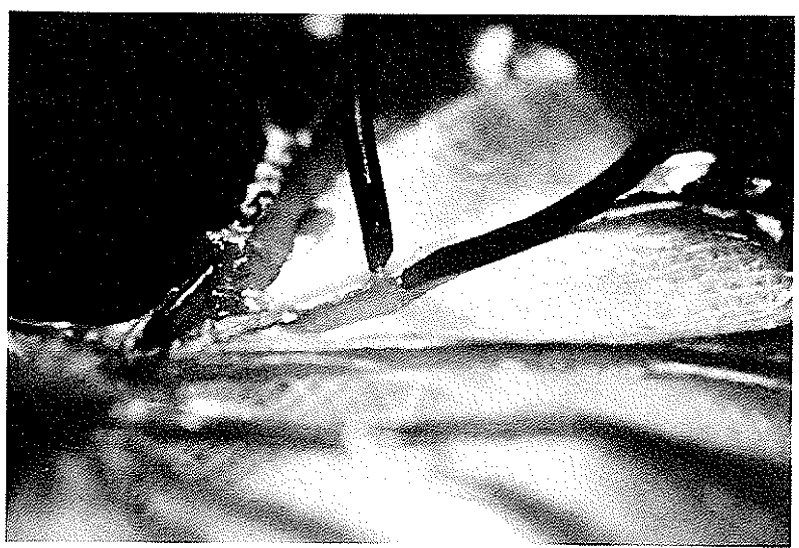

図 5 BLFによる小血管の処理

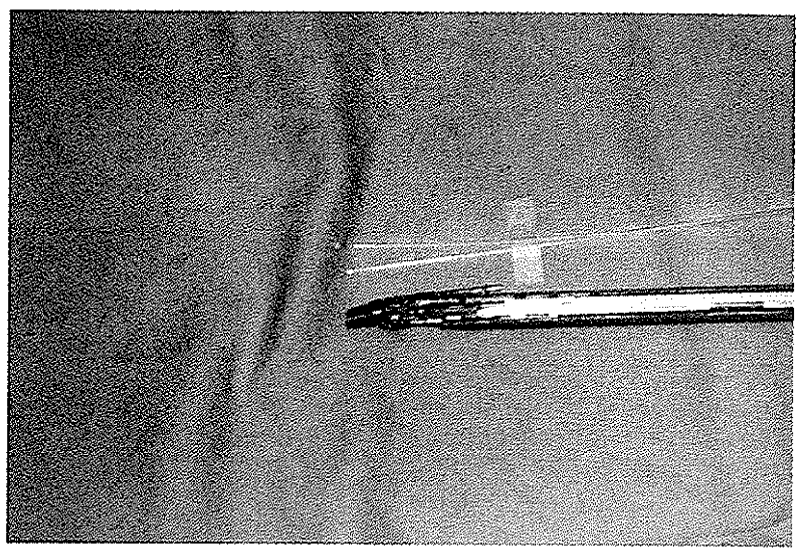

図 6 分光レーザーの内視鏡的利用

などのレーザー光に対する安全対策を笑施した。照射に 際してはピンセット先端を正確に目的部分にあて、組䄉 を把持した後，照射在開炲した（図 5)。同時にBLF使 用時の操作性（使いごこち）についても検討した。さら に内視鏡的後腹膜手術に纫用すべく，分光された導光 ファイバーを、考案した内視鏡用クリップの先端に装着 し、こ机在内視鏡チャンネルに聥入して内視鏡手術に応 用してみた（図6）。

\section{3. 結 果}

臨床芯用した全例炎（表 4)に示す。

陰谈内手術では小血管の止值には有効ですったが.2.0 mn以上の比較的太い静眽の止血では，総照射工ネルギー 量が平均 $30.5 \mathrm{~J}$ とBLFとしては比較的高エネルギーを 慗し，完全止血もしばしば因難ですった。しかし陰茥手 術における $1 \mathrm{~mm}$ 前後径の小血管の処理では効率よく凝固

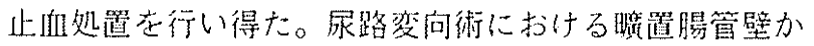
らの小血管出血の場合では，各出血部位に対して $2.0 \mathrm{~J}$

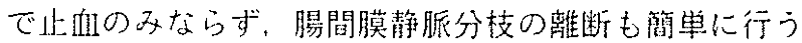
ことができた。内視鏡用BLFについてはまだ問題点は 多いものの，小组管の止血が可能でありBLFの内視鏡 手術への応用の可能性が示唆された。外尿道口付近の小

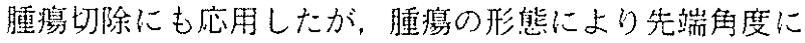


表 4 泌尿器科手術への応用

\begin{tabular}{|c|c|c|c|c|}
\hline 対象臟器 & 例数 & 目 & 効果 & 苚 \\
\hline 陰榙内 & 2 & 止 & 良 & 太い静脈には不十分。 \\
\hline 陰茎 & 1 & 止 & 優 & 小血管の好理に有効。 \\
\hline 腸間膜 & 1 & 止血切离 & 優 & 血管頀断も施行可能。 \\
\hline 管 & 1 & 止 & 優 & 離断部小出血は2Jで止血 \\
\hline 後腹膜腔 & 1 & 止 & 良 & 内視鏡的使用学試みる。 \\
\hline 外层道口 & 1 & 腫瘍切际 & 良 & 先端㢈度に工夫を要する。 \\
\hline
\end{tabular}

先端出力 $3 \mathrm{~W} ， 0.2$ 秒反復照射にて施行

工夫を要した。しかし総合的には，低出力で目的部分の 止血, 凝固求上び切除なよ゙の操作が容易に効率良く行い 得ることが確認できた。特に陰茥、腸間膜および腸管な よ゙，従来の方法では難洪する小血管に富む微細部分の処 理に有効であった。

\section{IV 考 察}

レーザーの生体組織に対する效果として, 蒸散（vaporization), 炭化(carbonization), 凝固(coagulation), 蛋白変性(denaturation) 㧍よび熱効果 (thermal effect) なよ゙が古り，用いるレーザーの種類，出力，照射法によっ てそ扟ぞ机の効果が強調さ机る゙的。Nd：YAGレー ザーは, Fruhmorgen`によって内視鏡的に使用できる レーザーとして臨床に応用されて以来, 泌尿器科領域で も経尿道的内視鏡手術に戈いて用いられ。 その長所が忍 められている"゙。 の非可視光で組織深達性があり, 本来その効果は凝固に 適している上言犼ている゙”。

$\mathrm{Nd}$ ：YAGレーザーの特長在生かしつつ，接触照射 学効果的に行うことを昌的として，BLFを考案したが， BLFを得るためには次の 2 点在解決する必琵があった。 第一にレーザー光をいかに分光するかという問題であ 万。

レーザー発振装琶でもって2本のレーザー光が発振可 能な装置は一般には入手不可能であった。装置的にも経 済的にも比較的安洒であり，発振装通より尊光された レーザー光を2 分割可能な力法を模索した結果, 光つア イバーカプラー法を応用することでこれは解決しだ。 この方法は通信，電力関係に执いて光ファイバーの通信 技術の一つとして奉用化されているシステムであるが, 1 本のファイバーで伝搬する光を 2 本のファイバーに分 岐したり，2本のファイバーで伝搬する光を1本のファ イバーに合流することが可能である。カプラー作製法の
一つとして融着延伸法がある。この方法は 2 本のファイ バーの側面を添わせ，加熱して融着する方法であり，次 第に融着部を延伸寸るに従いコア径が減少し，コアが接 近する。ここでファイバーに光を通しモニター下にこの 操作を進めると, やがて 2 本のファイバーを伝搬する光 の電磁界が重なり合い結合が生じる。モニターでこの結 合の度合いを测定しながら所定の結合が得られたよころ で加熱延伸を停止すればカプラーが作成される。このよ うにカプラーは比較的容易に作成され，しかもコンパク トである。さらにファイバーを变えることにより，様々 な出力下 $の$ 照射が理論上可能である。

第二に分光されたレーザー光を 2 点間の先端で一定の 角度でもって隣接照射させることが可能であるかに関し てである。

2 本のファイバ一より導か扎たレーザー光を最も有効 に目的組織に照射する角度は一般的には180度であると 考えられる。しかし現実には極的て困難であり、レーザー ファイバー間の合角が90度〜110度で南ることが実際的 であることを確認しだ"。したがってこの角度を保持 しつつ，確実に目的組織を把持する一方法としてピン セットの先端にファイバーを誘導して固定する方法を用 いた。

カプラー法で分配されたレーザー光は2本のファイ バーを在通り，ピンセットの耐脚に装着されたファイバー 先端より2点からの照射が可能になった。さらにBLF によるレーザー照射は極めて限局した部分をピンセット 操作に準じて把持し必瑟最小限のエネルギーを加えるこ とができる特長を有している。今回行っだ基礎実験の結 果として考えられる問題点として以下の点をあげてみた。

(1) 先端径と血管径との関係による限界

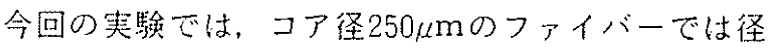
$1.5 \mathrm{~mm}$ 程度の血管が至適籍囲としては限界であり，こ机 以上太い血管になると単位面積あたりの必要エネルギー 量が增加し，効率は㦞くなることが予想されるため太い 血管処理に扒いてはさらにハードウェアーの改良を檢討 する必要がある。

(2) ピンセット先端部の過熱化

目的組織に長時間照射することによりピンセット先端 部分の過熱化が抗こると考えられる。この場合照射によ るファイバー周围のレーザー光のback scatteringが大 きくなっていることが想定され，周囲組織の障害が比較 的広範囲に及ぶと考えられる。これを防ぐためにも凝固 切開に適切なレーザーエネルギー量を知ることが必要で ある。今回の基礎的奏験で至適照射条件を設定したが， この条件下に照射することが必要である。 
(3) ピンセット先端部を離す際に再出血を来たす可能 性

原因として以下のことが考えられる。すなわちレ一 ザー照射中はピンセット先端部はきわ加て高温になるた め, 接触部分の膠原線維なよ゙の組織は变性融解を生じ, ゾル状になっていると考えられる。レーザー照射終了後 直ちに，照射部位では急激な温度低下がおこり，ゲル状 を含み硬化する結果溶接効果が生じ，それを外力で離す 際に熱性凝固塊の剥離が生じ出血すると考えられる。組 織把持を解除する寸前まで照射を行うこよにより高温状 態を保つことで，ある程度この現象を防ぐことができる。

\section{(4) ファイバー先端の損傷}

本法は細いコア径のベアファイバーを直接目的部分に 接触させて照射する方法であるため簡便ではあるがファ イバー先端の消耗が激しくなる。手術眭にはこのため効 率が悪くなることも予想さ机るため，ファイバー先端の 篟造についてさらに検討する必要がある。しかし照射後 の経過に执いて，消耗ファイバーにより暴物反応をおこ した例は認められなかった。

新井”はNd：YAGレーザーの各種機能について基 碟実験を行っている。その凝固能に関する検討で, 径的 1.5mmのット血管に対して通常の方法で照射した場合， 炭化によって虽裂を来たし，しばしば出血するこよを観 察している。そこで血液にひたしたスポンゼルを放てて 照射するか，レーザー内視鏡用のマイクロチップ在用い るこ上在勧めている。こ扎らにより血管外より力在加え 近流荙一眭遮断したうえで照射すると比較的太い伹管で も処理できるこよを述べている。この操作はBLFを用 いることにより容易に遂行可能である。奏際の手術に際 してもBLFは前述のご上き照射法を行うこ上により，

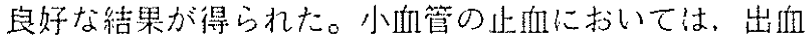
部分を確認すると同時に同部分を把持照射することによ り従来の結装による此血に比べて短時間で行える。すな わち BLFの使用法は，バイポーラー瞥気メスと基本的 には同様である。ところがバイポーラー電谷メスでは， 把持の方法㧍よ心゙目的組織の相異による通電の変化， シャント電流なよ゙による効果差がしばしばみられる12》。 BLFを用いると，レーザーの特性に上り安定した出力 が期待でき譩照射の防止といった利点がある。従来の レーザー手街に批ては術者は単一ファイバーよりの画 一的な照射法のみで，様々な操作を行えなかった。しか し，ピンセットによる把持操作が加えられることにより， 術者は把持感を得ながら，目的組織に完全かつ確実に レーザー照射を施行できる。

近年新しい内視鏡手術 (Endoscopic Surgery) が日
常的に行われるようになり，特に内視鏡下に利用可能な $\mathrm{Nd}$ : Y AGレーザー，KTPレーザーなどを腹腔鏡胆媇 摘出術に応用し，電気メスと比較してその有用性を検討 した報告もみら扟る(3)。泌尿器科領域においても内視 鏡手術の発達はめざましくEndourologyとしてさらに 腹腔鏡下手術が加えら犯行，腹腔鏡による停留精巣の 診断 ${ }^{(5)} 167$, 胥盤内リンパ節郭清術(7)18), 腎摘出 術19120221)，副腎摘出術22)23》などが行われている。 この種の手術では止血, 結㷊, 切断の同時操作が要求さ れ，さらに特殊な器具鉗子類が必要になる。以上の必要 性より，われわれはBLFを内視鏡手術に適用すべく一 方法を考案した。内視鏡用クリップアプライヤーの先端 部分に分光した 2 本のファイバー交装鄯してクリップ操 作に準じてレーザ一を照射してみた。現段階ではその効 果を諭じ得ないが，BLFの内視鏡手術への応用も夢で はない。

\section{$\mathrm{V}$ 結 語}

1.ファイバーカプラー法により2本のファイバーに分 光することが可能であり，分光によるエネルギー損先 は少なく $(6.0 \%)$, 左在の出力差 $(2.0 \%)$ も最小限 であった。

2. BLFの基䃈実験上して，ラット腎血管在対象にも

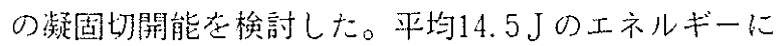

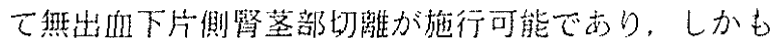
組織学的㯢討よりその熱效果はきわめて限局している ことが確認された。

3、臨床的にBLFを奏際の泌尿器科手術に応用し， そ の効果老検討した。比較的低出力で目的部分の外科的 処理が容易に効涐上く行い得ることが確認さ机た。。 らに内視鏡的使用も可能であることが示吺された。

稿を終えるにあたり，終始ご指導とご校閲を睗り声し

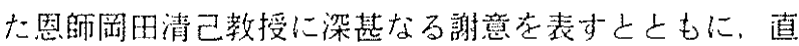
接ご指望いただきました清潼修二講毁に心から感謝いた します。またご協力いただきました(椒エムアンドエム瀬 戸氏打よび教室員諸见に御礼申上げます。

\section{参考文献}

1) Daikuzono,N. and Joffe, S.N.:Artificial sapphire probe for contact photocoagulation and tissue vaporization with the $\mathrm{Nd}$ : YAG laser. Med. Instrum., 19:173-178, 1985

2）比企能樹，山尾哲彦，嶋尾 仁，小林伸行：コンタ クトYAGレーザー内視鏡. BME 11：513-517. 1987 
3) 大井知教：泌尿器系組織に扩けるNd：YAGレ一 ザー照射の基碟的研究. 日大医誌。49：413-424, 1990

4) 半田澄雄：動物実験と動物福祉について, 福岡医誌, $83: 127-130,1991$

5) 桜井靖久，菊地 真：レーザー光の生体への作用機 序.レーザー医学 基礎と臨床, 中山翌店, 1979, pp $27-40$

6) 久保宇市: 固体レーザー，医用レーザー入門，オー 么社, 1985, pp50-55

7) Fruhmorgen, P., Bodem, F., Reidenbach, H.D., Kaduk, B., Demling, L. and Brand, H.: The first endoscopic laser coagulation in the human G.I. tract. Endoscopy, 7 : 156-157, 1975

8) 岡田清己, 平野大作, 吉四利夫, 朝岡 博, 野口幸 啓，賀屋 仁，斎藤忠則，遠藤克則，天谷龍夫，尾 上泰彦，熊谷振作，北島清彰，岸本 孝 : 膀胱腫疾 に対する経尿道的 Nd-YAGレーザ一の治療効果.

日泌家会誌，73：898-903，1982

9 ) 新井克志：Nd-YAGレーザーの基礎と臨床, 日レー ザー医会誌, 11：43-56，1991

10)川上 登: 光ファイバーカプラ, NEW GLASS, $6: 48-58,1991$

11）清滰修二，吉川哲夫，大啓教，仲野智，阔田清 己：Bipolar Laser Forceps（双極レーザーピン セット)の開発とその応用一組織接合への試み一。 日レーザ一医会誌（第11回日本レーザー医学会大会 論文集）655-658，1991

12) Kramolowsky, E.V. and Tucker, R.D.: The urological application of electro-surgery. J. Urol., 146:669-676, 1991

13）大友裕美子，下村一之，石㱦陽一，野家 環，阿部

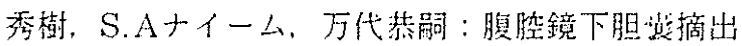
術とレーザー，日レーザー医会誌，12：21-26.1991

14) Winfield, H.N., Donovan, J.F., See, W.A., Loening, S.A. and Williams, R.D.:Urological laparoscopic surgery. J.Urol. 146:941-948, 1991

15) Silber, S.J. and Cohen. R.: Laparoscopy for cryptorchidism, J.Urol. $124: 928-929,1980$

16）福崎 篤，折笠精一：停留精果の腹腔鏡。泌尿器外 科, 5:105-108, 1992

17) Schuessler, W.W., Vancaillie, T.G., and Reich,H.: Transperitoneal endosurgical lymphadenectomy in patients with localized prostate cancer.
J.Urol. $145: 988-991,1991$

18）寺地敏郎, 村田公志, 荒井陽一, 大石賢二, 吉田修： 腹腔鏡による骨盤内リンパ節郭清街. 泌尿器外科. $5: 109-113,1992$

19) Clayman, R.V., Kavoussi, L.R., Soper, N.J., Dierks, S.M., Meretyk, S., Darcy, M.D., Romer, F.D., Pingleton, E.D., Thomson, P.G. and Long, S.R.:Laparoscopic nephrectomy:initial case report. J. Urol. 146 : 278-282, 1991

20）東原英二，龟山周二，田中良則，堀江重郎，佐山孝， 狩野宗英, 朝䕬裕之, 奴田原紀久雄, 本間之夫, 喜 和田滋，阿兽佳郎，腹腔鏡下腎摘出術（動物奏験及 び臨床応用)，日泌尿会誌８3：395-400，1992

21）小野佳成，佐橋正文，大島伸一：腹腔鏡下腎摘出術, 泌尿器外科, $5: 115-119,1992$

22）清滝修二, 吉田利夫, 野垣譲二, 賀屋 二, 岡田清 己:内視鏡的副腎摘出術, 泌尿器外科, 5:121-126, 1992

23）東原英二，田中良則，堀江重郎，有賀誠司，奴田原 紀久雄, 本間之夫, 营和时滋, 阿兽佳郎：腹沿鏡下 副腎摘除街，日泌尿会誌，83：1130-1133，1992 